\title{
医療機関に対する経営・ マーケテイング視点からの考察
}

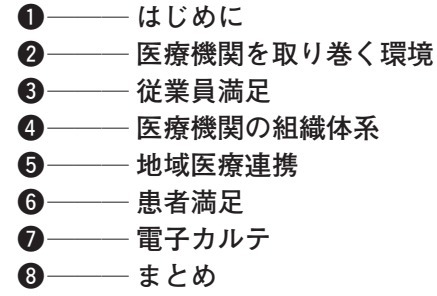

\section{冨田 健司}

静岡大学 人文学部准教授

\section{1)—はじめに}

近年，医療機関を取り巻く環境は厳しさを 増し，各医療機関とも存続と成長を実現する ためにさまざまな経営努力を必要としている。 都市部を中心とした診療所の増加，医療ス夕 ッフの不足，医療費抑制策，医療ニーズの多 様化，少子高齢化，医療消費者による情報開 示要求の高まりなどの要因から, 医療機関に も経営・マーケティングの実践が問われてい る。こうした実務的な流れとともに，『組織科 学』や『ビジネス・インサイト』などで特集 が組まれ, 経営学系のアカデミック領域でも 医療を学問的な視点から捉える動きが広まっ ている1。

企業の経営活動を考える際，内部環境と外 部環境を捉え，それらの環境の中で事業を営 まなければならないため，本稿でも同様に医 療機関の内部環境と外部環境に目を向ける。 具体的には, 内部環境として従業員満足と組 織体系とを，また外部環境として近隣医療機
関との地域医療連携と患者満足とを，また両 方に共通する課題として電子カルテの問題を 医療機関は特に考慮しなければならない。本 稿では，これらについて順に議論を展開して いく。

よって，本稿の構成は次のようになる。ま ず，次の第 2 節では医療機関を取り巻く環境 を医療機関数，医療費，さらには国の政策の 視点から整理する。そこから浮き彫りにされ る内部環境としての従業員満足と組織体系と の課題を第 3 節，第 4 節で，また外部環境と しての地域医療連携と従業員満足との課題を 第 5 節，第 6 節で考察する。さらに，内部環 境と外部環境に共通な課題の電子カルテにつ いて第 7 節で考察していく。最後の第 8 節で 本研究のまとめを行い, 今後の研究課題を提 示する。

\section{2—医療機関を取り巻く環境}

われわれは無意識に「病院」と呼ぶが，医 療法によると「病院」とは医師や歯科医師が 人々のために医業や歯科医業を行う場所であ り，20 名以上の患者を入院させる施設，つま 
り 20 床以上のベッドを有する施設をいう。そ して，それ以下のベッド数の施設が「診療所」 に分けられる 2)。「医療施設動態調査」によれ ば，2007（平成 19）年 9 月末時点におけるそ れぞれの施設数は病院が 8,862, 診療所が 99,546，歯科診療所が 67,807 である。1980 年 代までは病院，診療所ともに増加していたが, 1990 年以降，病院数が減少している（診療所 は増加を続けている)。病院数が減少傾向にあ る要因としては，地方において医師の確保が 困難であることが大きい3)。それにより，病 院の診療科や機能の縮小を余儀なくされ, 経 営が悪化する。となると, さらに医師の確保 が困難となる負の連鎖が作用してしまう。

人材の問題以外に，医療経営を考える際に は医療費の問題が大きい。医療費はかつて出 来高払い方式が取られていたが，定額払い方 式が拡大傾向にある。出来高払い方式では治 療にかかった費用（点数）で医療報酬が決ま るが, 定額払い方式では患者の病気（診断群 分類）によって医療報酬が決まる。定額払い 方式では無駄な医療が省かれ，医療費の削減 が期待できるメリットがある反面，医療機関
が医療行為を削減することにより，患者が不 利益を被る恐れも指摘される。

1989 (平成元) 年度からの医療費の推移は 図－1に示される。2000（平成 12）年，2002 （平成 14）年の 2 度，診療報酬改定の影響を 受け，国民医療費は対前年比 $-1.8 \%$ と $0.5 \%$ 削減となったが，国民医療費，国民 1 人あたり医療費ともに年々，増加しており， 15 年ほどの期間で 1.4 倍ほどに膨張している。

こうしたなか，2005（平成 17）年 12 月の 政府与党医療改革協議会において「医療制度 改革大網」が示された。この目的は，国民の 医療に対する安心・信頼の確保と, 質の高い 医療サービス供給体制の構築にある。また構 造改革の方針は次の 3 点 - 安心・信頼の医療 の確保と予防の重視，医療費適正化の総合的 な推進，超高齢社会を展望した新たな医療保 険制度体系の実現一からなっている。このう ち, 経営学・マーケティング視点からの議論 として特に重要となるのは「安心・信頼の医 療の確保」である。

医療制度改革大網において, 安心・信頼の 医療の確保は(1)医師不足問題への対応，(2)地

口图-1

\section{国民医療費と国民 1 人あたり医療費の推移}

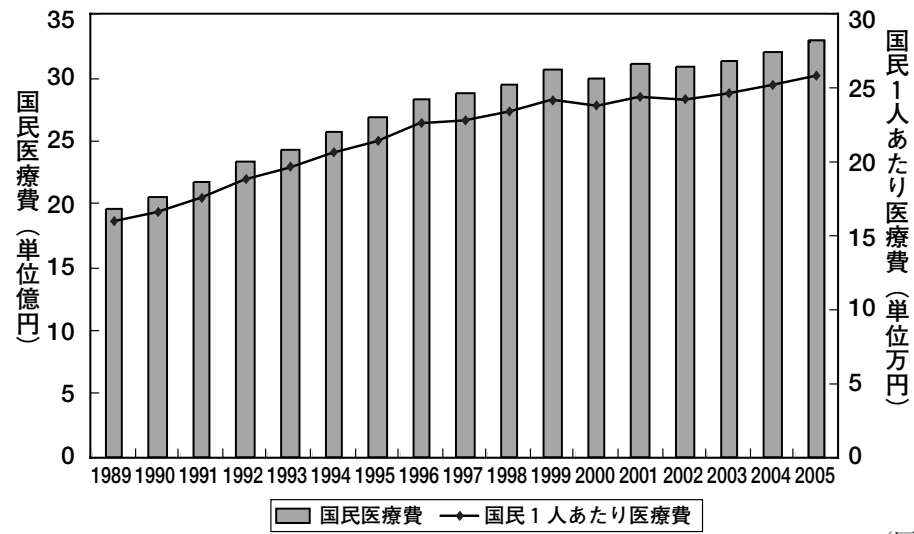

(厚生労働省 HPより作成) 
域医療の連携体制の構築，3患者に対する情 報提供の推進, (4)遠隔医療の推進等, (5)信頼 できる医療の確保, 6医療法人制度改革, か ら構成される。そこで, 本稿では(1)の対応策 となる従業員 (医療従事者) 満足の課題と組 織体系の課題, (2)の地域医療連携の課題, (3) と(5)に関連する患者満足の課題，さらには(2), (3), (4)，(5)に関連する電子カルテの課題とい った 5 点について議論を展開していく。

\section{(3) 従業員満足 4)}

特に地域における医師不足が深刻化してい るが，医師だけでなく看護師など医療従事者 は資格, 専門的知識・技術, 経験を要するた め, 需要に比べて供給が少ない。前節でも述 べたように，医療スタッフの不足は医療サー ビス低下につながり,さらには医療経営その ものの低下につながってしまう。

企業で働く日本の従業員と比較すると医療 従事者は組織に対する帰属意識が相対的に低 く5), 組織のトップである病院長の権限が弱 い。印南（1998）によると, 彼らの医師に対 する権限は調整のみであり，指揮権はない。 問題のある医療スタッフを再教育したり, 解 雇することは非常に困難である。そのため, 医療スタッフをマネジメントすることはきわ めて難しく，医療機関にとってこれが重要な 課題となる。

Vroom（1964）は，職務満足と生産性との 因果関係には疑問が残るが, 職務満足と離職 率，欠勤との間には負の関係があることを見 出した。この結果に対して, 高橋（1996）は, 組織間の移動が容易な環境において当てはま るとしている。医療の場合, 医療従事者に帰
属意識が少なく, 有能な人材は売り手市場で あるため，組織間の移動は容易といえよう。 離職や欠勤が起こると適切な医療サービスを 提供できなくなるため, 患者満足の前提とし て従業員満足を高めていかなければならない6)。

どうしたら従業員満足が高まるのかを考え るとき, その方策は 1 つに留まらないが, 従 業員に対して明確な目的・目標を提示し, 動 機づけを行うことは共通している（Noumann 2002）。動機づけを考える際, 欲求に着目した 代表的な研究に Maslow（1954）の欲求階層 説がある。彼によれば，人間の欲求には生理 的欲求, 安全の欲求, 所属愛の欲求, 自尊の 欲求, 自己実現の欲求という 5 つの欲求があ り，それらが低次から高次へと順に階層をな している。そして, 自己実現の欲求は他の 4 つの欲求とは異なり, 成長動機による欲求と 区別される。それは, 外部から得るものでは なく人々の内部にあるので内発的動機づけと 呼ばれ, 潜在的可能性を最大限に発揮し実現 することである。

McGregor（1960）は Maslow の生理的欲求 や安全の欲求に基づく考え方を X 理論, 所属 愛の欲求, 自尊の欲求, 自己実現の欲求に基 づく考え方をY 理論とした。X 理論とは, 人々は労働を嫌い, できれば意けたいと思う ため, 命令や処罰によってのみ働き, 野心が 無く安全を望む行動を前提とする。一方, $\mathrm{Y}$ 理論とは, 人々は仕事に目標を立て, それに 向かって努力し, 満足を得る行動を前提とす る。医療従事者の場合, 多くはもともと患者 を助けたいという強い欲求を持っており, $\mathrm{Y}$ 理論に基づく。そのため, 医療機関は医療又 タッフの業務を細かく規制するよりも，性善 説に基づき権限を委譲し，任せた方が良い。 
Deci（1975）によると，内発的動機づけ理 論とは，特別な報酬がないのにも関わらず， その活動自体が目的となって満足（喜び）が 引き出される状態のことをいう。人々は行動 により，自らの環境を処理し，効果的な変化 を生み出すことができたとき満足を実感する。

企業における内発的動機づけの具体的な一 例として QC (Quality Control：品質管理） サークルを挙げることができる7)。QC サーク ルとは，職場内で品質管理活動を自主的に行 う小グループのことで，全社的品質管理活動 の一環として自己啓発，相互啓発を行い，QC 手法を活用して職場の管理と改善を継続的に 行っていく。QC 活動は従業員による自主的 な活動であり，経営者や管理者はその支援に とどまる。医療においても，医療の質とサー ビスの向上を狙ってさまざまな機関が $\mathrm{QC}$ サ ークル活動を行っている。

練馬総合病院では役職者有志懇談会を機に, 病院からの指示でなく, 管理職が医療の質向 上のために積極的な活動を行うべきであると 考え，自ら率先して $\mathrm{QC}$ サークル活動を始め た。「医療における信頼の創造」を目指した活 動はMQI（Medical Quality Improvement) 活動と名付けられた。1996（平成 8）年から 毎年統一主題を設定して，全ての従業員がチ 一ムに分かれ，業務改善を模索している。1 年に及ぶその活動成果の発表大会は毎年 12 月 に開催され，地域に開放されているため，近 隣住民も視聴することができる。

医療機関の従業員は Y 理論傾向が強いため, 報酬, 勤務形態の整備だけでなく，こうした 自己啓発を従業員が行うことのできる仕組み を医療機関は構築し，従業員の満足や士気を 高めていかなければならない。

\section{4一医療機関の組織体系}

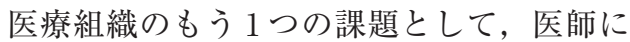
権限が集中する封建的な組織体系を指摘する ことができる。病院長に医師が就くことは法 律で定められているが，それ以外の要職にも ほとんどすべて医師が就いている。また治療 のチーム内でも医師がトップに立ち，その下 に看護師, 薬剤師, 理学療法士, ソーシャル ワーカーなどが付くトップダウン形態が一般 的といえる (図一2)。

ここではチーム内における学習を考えたい。 この関係におけるチームメンバーの知識・情 報の学習を図示すると図ー3 となる。眓にお いて，A，a，B，bは専門知識・(専門的見地 からの）患者情報を表し，その質と量に関し て言えば $A>a ， B>b$ の関係が成立する。医師 は専門知識・患者情報である「A」と非専門 知識・患者情報である「b」を有しており， 他のチームメンバー（看護師，薬剤師，理学 療法士，ソーシャルワーカーなど）は当該の 専門知識・患者情報である「B」と非専門知

口図-2

一般的な医療機関におけるチーム内の関係

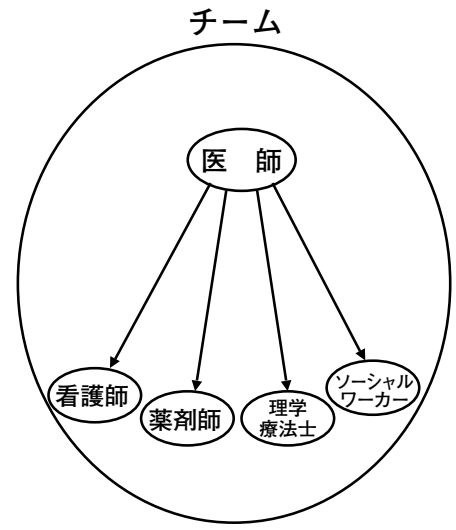


口图-3

知識・情報の学習

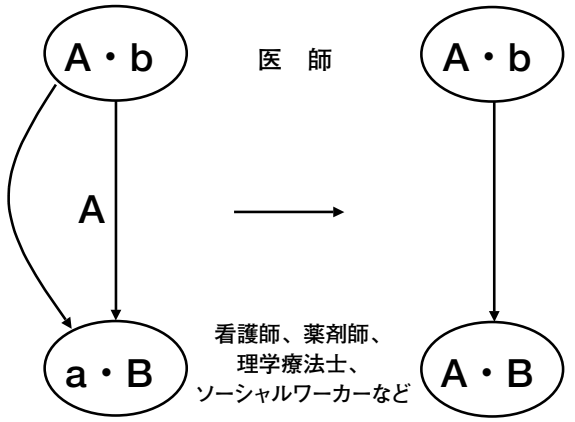

(A,a,B,bは専門知識・患者情報を表し、A>a, B>bとする) (Heller (2006) をもとに作成)

識・患者情報である「a」を有している。それ ぞれは自らの職種の専門知識に関しては高い ものを持っているが，職務が完全に分割され ているため，他の職種の専門知識に関しては 知らないこともある。

メンバー内の関係が図ー2のようなトップ ダウン型の場合，チームのトップである医師 が有する「A」の専門知識・患者情報は他の
チームメンバーに伝達, 学習され, 「a」の知 識・情報が「A」となる。しかし，この組織 形態では一方向のコミュニケーション・学習 通路しか持たないため，看護師などの専門知 識・患者情報である「B」を医師が学ぶ機会 は少ない。そのため, 医師の「b」の知識・ 情報は「b」のままでしかない。

これに対して，静岡がんセンターの病棟で は別の組織図を有しておいる。病棟では 24 時 間患者をケアする看護師の方が，患者の状態 をよく分かっており，患者の情報を多く持っ ているため，看護師の位置づけが高い。患者 ケア中心の組織図では，看護師長がトップに 立ち，その下に医師や看護師がついている点 が通常の組織形態とは大きく異なる。この組 織形態は患者を中心に置いた時にもっとも効 果的な治療を行い易い組織として勘案された ものである ${ }^{8)}$ 。チーム内の関係は図ー4に示さ れる。

多職種チーム医療と名付けられるこの組織 体系は，患者に最善の治療とケアを提供する

口图-4

静岡がんセンターにおけるチーム内の関係

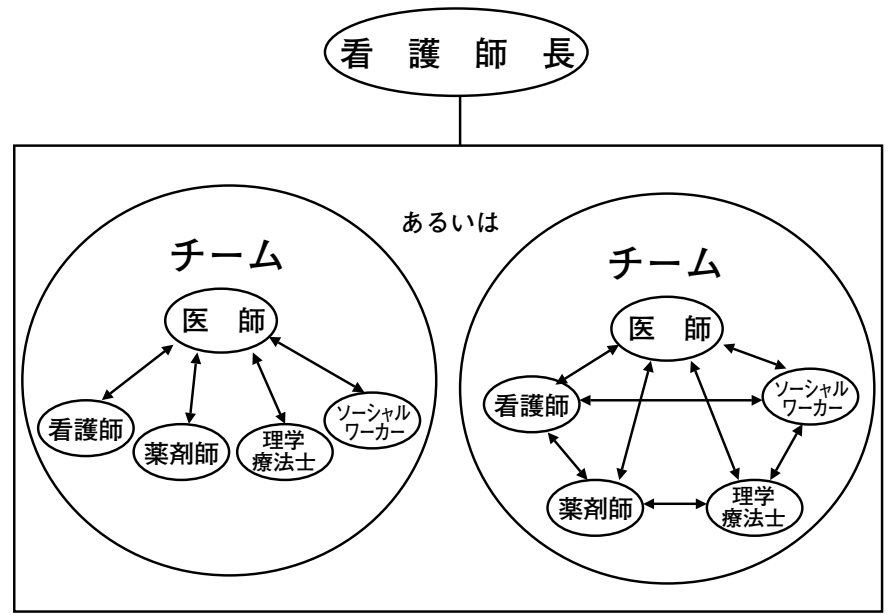


システムの構築を目指したものである。医師 と他のメンバーとの距離が近い双方向的な関 係，あるいはワークショップ的な関係を構築 している。フラットな組織形態であるため, 各メンバーは自分の専門的見地から提案や意 見を言い易い環境が作られている。院内には チーム医療推進委員会も設けられ，チーム医 療が重視されている。チーム医療では効率以 上に効果が優先され，この姿勢は理念によっ て守られており，全員に徹底されている。

この場合における知識・情報の学習を考え ると図ー5の関係になる。医師の専門知識・ 患者情報が他のメンバーに伝達, 学習されて, もともと「a」の知識・情報しかなかったもの を「A」とすることができる。同様に，たと えば看護師の専門知識・患者情報も医師に伝 達, 学習されて「b」の知識・情報を「B」と することができる。この結果，メンバー全員 が「A」，「B」の専門知識・患者情報を有する ことが可能となる。いうまでもなく，こちら の組織形態の方がチームメンバー全員で知識 や情報を学習, 共有できる環境といえる。

他産業の組織と比べて医療機関の場合, 異 なる専門職の集まりであるため, 多職種チー

\section{口图一 5}

\section{知識・情報の学習}
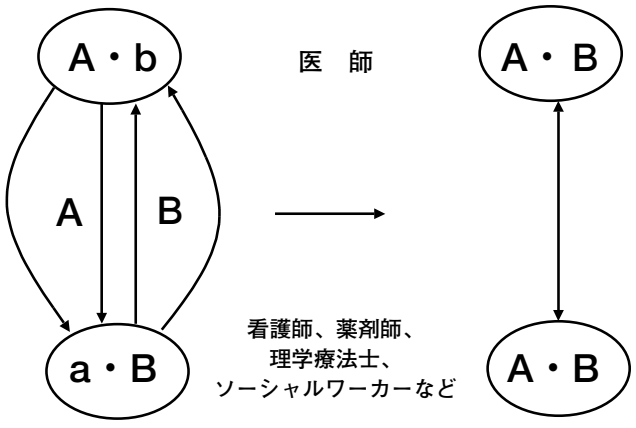

ムのように組織内関係がフラットであるなら， 上記の関係が成立し易い。しかし一方で，こ の組織形態が機能するには，それぞれの専門 職能力が長けていること，チームメンバーに 相手の知識・情報を学習する（受け入れる） 意欲があること, チームメンバー内にパワー 関係が無いこと，チームメンバーが目的を共 有していること，といった 4 つの条件が必要 となる。

\section{5一地域医療連携}

前節の多職種チーム医療はチームメンバー どうしによる協調関係であるが，地域医療連 携とは医療機関どうしによる協調関係のこと である。

医療機関は施す医療の程度一軽度の 1 次医 療（プライマリケア）, 2 次医療，高度な 3 次 医療一に分けられ，同時に規模に応じて分け られる。そして, 1 次医療を行う診療所から 3 次医療を行う大病院 ${ }^{9}$ への患者紹介が頻繁に 行われている。また，患者の病状と扱う治療 レベルに関して，急性期，亜急性期，回復期， 慢性期に分けることができる。急性期病院の 役割は急性疾患の患者に高度な救急医療や集 中治療を施すことであり，患者の病気や怪我 の進行を止め，それらの回復が見込める目処 をつけることである。急性期病院における患 者の在院日数は 14 日以内が目安とされている ため，治療により病状が改善した患者をリハ ビリテーションなど回復期治療を行う医療機 関や慢性期治療を行う医療機関へ戻していか なければならない（「逆紹介」という）10)。つ まり，医療機関には機能分化が求められてい る ${ }^{11}$ 。 
政策により，医療機関は他の医療機関と連 携しなければならない点が一般企業と大きく 異なる。同時に機能分化も推進されるため, 各医療機関は異なる治療レベル（急性期，亜 急性期, 回復期, 慢性期) の医療機関に対し ては競合関係とならず，ネットワークを構築 しやすい。独立関係にある複数の組織が，互 いの戦略意図を実現するために協働する緩や かな組織間関係は, 経営学の枠組みにおいて 戦略的提携として捉えられる ${ }^{12)}$ 。

戦略的提携においては組織間学習の重要性 が Hamel（1991）によって指摘されている。 またInkpen（1996，2000）によると，組織は 他の組織から知識を獲得したり，協力による 知識創造を目指している。医療連携において, 地域の中核病院は診療所の医師や看護師を対 象としたセミナー等を行うことが多く，その 際には診療所の一方的な学習でしかないが, 開放型病床では被紹介の病院医師と紹介側の かかりつけ医とが共同で診療にあたるため, 知識の融合や創造が生まれ易い。特に暗黙知 の移動はパートナー間のインフォーマルなコ ミュニケーション活動に依存するため, 医療 連携には信頼とコミュニケーションが不可欠 となる ${ }^{13)}$ 。

信頼関係はさまざまな社会の枠組みにおい てもっとも重要なものであり，相手に安心感 と行動予測性を与えることができる（Zimbardo 1980)。Lindzey and Aronson（1985）に よれば，双方が認め合い，助け合うことから 相互信頼が生まれる。つまり，(1)相手と好意 を相互に交換し合う，(2)相手を良心的な人だ とみなす，(3)双方が互いにそれぞれの価值観 や規範などを認め合う，(4)双方が互いにそれ ぞれの要求を獲得, 実現できるよう助け合う,
ことから相互信頼が生まれる。

若林（2006）によれば，組織間取引におけ る信頼とは規範が共有されており，義務と権 利の関係について暗黙の共同理解が安定して いる状態をいう。信頼には相手の誠実さや好 意など個人的な関係が必要であり（Ring and Van de Ven 1992)，組織間に信頼関係が構築 されれば，パートナー企業の将来的な行動の 不確実性が削減される（酒向 1998, Ring and Van de Ven 1994) ${ }^{14)}$ 。さらに, コミュニケー ションが活性化するため, 関係は安定的, か つ発展的なものとなる（Uzzi 1997）。Das and Teng (1998) やDyer and Chu（2000）によ れば，信頼関係の構築によってパートナー間 に互恵的な協力行動が生まれ，組織間のすり 合わせや暗黙知における知識共有などが可能 になる。

さて，それでは信頼はどのようにして構築 されるのだろうか。この問題を考える際，信 頼を細分化すると分かりやすい。酒向（1998） によれば，信頼は(1)能力に対する信頼（相手 が技術・経営能力の点で十分に役割を果たせ るという期待), (2)約束遵守の信頼（相手が文 書や口頭での約束を守るであろうという期待, (3)善意に基づく信頼（ある特定の範囲の要求 に敏感に対応するだけでなく，それ以外の部 分にも対応するという期待）に分けられる。 彼女の議論は発注企業とサプライヤー企業と いった企業間関係における信頼を前提として いるが，医療連携の場合にも応用させること ができる。(2)の善意に基づく信頼は高次元の 信頼であるため，この信頼を抱くことができ れば，組織間には深い信頼関係が構築される。

他に医療ネットワークの1つとして位置づ けられる近年の傾向として, 医療モールの存 
在を挙げることができる。独立した異なる専 門の診療所がショッピングセンターの一角な どに集まっているため，患者にとって移動の 手間を省くことができ，併設されたレストラ ンで食事をしたり買い物をすることもでき, 利便性が高い。こうした医療モールは集客力 の高いところに建てられることが多いため， 多くの患者に来院してもらうことができ, 開 業コストを抑えられるメリットがある。さら に，調剂薬局においても医療モールへの参加 によって効率的に患者を集めることができる。

\section{6 患者満足}

患者满足度調査は多くの医療機関で行われ， 学術論文においても患者満足を取り上げたも のが多くなった。しかし，大半が医療従事者 によるものであり，その多くはDonabedian （1980）の構造・過程・および成果モデルに基 づき，医療の質の評価が行われてきた。Dedhiya and Kong（1995）や水野ら（1999）が 指摘するように，成果に対する評価としてこ れまで死亡率，罹患率，あるいは剖検率とい った客観的指標が重視されてきたが，近年で は患者の幸福感や QOL といった患者自身の 知覚・主観的評価も併用する方向へと進んで いる。

冨田（2003）はリレーションシップ・マー ケティングの視点から, 患者自身の知覚・主 観的評価から生ずる患者満足の要因について 探った。質問票調査において共分散構造分析 を行った結果, 予約の利便性が患者満足に最 も大きな影響を及ぼしていることが分かった。 他にも, 待ち時間の短さ, 個別の要求を受け 入れてくれること, 医師の優しい対応, 正確
な治療も大きな要因となっていた。この調査 では患者である回答者の負担を減らすため, 医師に対する質問項目に限定したが，医師た けでなく看護師や他の医療従事者に対しても 患者は質が高く親切な対応を望んでいること は明らかである。この結果から，患者の待ち 時間に対する方策を考えていく必要がある。

良い病院ランキングで上位に挙げられる五 の橋キッズクリニックでは予約はもちろんこ と，患者の待ち時間にも気を配っている。患 者である子供たちが不安を感じないよう, 待 合室ではDVD ビデオを流し，木の形をした 身長計，木製列車，二モが泳ぐ水槽など子供 の興味深いものを置いている。さらに，キッ ズコーナーと呼ばれる部屋には木製のおもち やを置き，子供の想像力が掻き立てられるよ う配慮している。

こうした医療の周辺的サービスに対して患 者は判断することができるが，医療の質その ものに対する判断は専門的知識を要するため, きわめて難しい。医療者と患者との間には大 きな情報の非対称性が存在するので，医師主 導による，医師の都合に基づいた医療サービ スが施される危険性がある。また, 専門家集 団である医療者は患者に対する責任よりも同 僚に対する信義を重視する傾向にある（印南 1998, Gillon 1986）。その上，医療サービスに は患者不満足が顕在化しにくいといった性質 がある。それは，たとえ医師が治療の手を緩 めても患者にはそれが分からないこと，医療 サービスは患者の命に直結するため不満を表 しにくいこと，さらには通院途中での他医療 機関への変更（ブランド・スイッチ）が困難 であることに起因する。

しかし，患者満足を高めるためには，医療 
者は患者やその家族に分かり易く情報提供す ることが求められる ${ }^{15)}$ 。患者が自らに施され る手術や検査, 投薬などの医療行為について 医師から詳しく説明を受け，理解した上で (informed)，医師の治療方針に合意すること (consent) をインフォームド・コンセントと いう。その際には, 選択される治療行為の内 容だけでなく，その副作用や成功率，予後， 代替治療までを含んだ情報を提供しなければ ならない16)。

一般的な財（サービス）の購入と違って， 医療サービスを受ける場合，患者は病気や怪 我といった負の肉体的・精神的状態にあるた め, 不安を感じやすい。だからこそ, 患者満 足には患者と医療スタッフとの信頼関係の構 築が不可欠となる。山岸（1998）によると， 「安心」とは，相手が自分を搾取する意図を持 っていないという期待の中で, 相手の自己利 益の評価に根ざした部分のことである（社会 的不確実性が存在しない状況についての認知 である)。また「信頼」とは，相手が自分を搾 取しょうとする意図をもっていないという期 待の中で，相手の人格や自分に対して抱いて いる感情についての評価に基づく部分に限ら れる（社会的不確実性が存在する場合のみで ある)。信頼は，社会的不確実性が存在してい るにもかかわらず，相手の（自分に対する感 情までも含めた意味での）人間性ゆえに，相 手が自分に対して酷い行動をとらないだろう と考えることである。一方，安心は，そもそ もそのような社会的不確実性が存在していな いと感じることを意味する。

社会的不確実性の大きな環境においては, 特定の相手との間にコミットメント関係を形 成し，その関係内部での社会的不確実性を低
下させる方法がある。山岸（1998）やGranovetter（1973）によれば，強い紐帯で囲ま れている人々は安心することができるが，そ の反面，情報の量が制限されるといった機会 コストを支払うこととなる。そのため, 患者 や家族は担当医師との紐带を強めた上で，七 カンド・オピニオンを求めていくことが必要 であり，厚生労働省や医療機関はその制度を 充実させる必要がある ${ }^{17) 。 ~}$

また，患者満足を考える際，これまでの先 行研究において患者の区分けはほとんど行わ れてこなかったが, 治癒が可能な患者とそう でない患者とでは満足の次元も異なれば，そ の要因となる評価項目も異なってくるため, 患者を何らかの基準で細分化して方策を考え ていかなければならない18)。相対的に見て, 治癒が可能な場合は医療提供者の技術（患者 にとっての肉体的満足感) が, 治癒が不可能 な場合はコミュニケーションや信頼, 安心 (精神的満足感) がより重要になっている。特 に終末期医療の場合, 患者の「満足」を考え ることは難しく, 不安の除去や軽減が医療機 関の目指すものとなる。

その上で, 患者満足を考える際には 3 人の 顧客を考慮する必要がある。医療サービスを 受ける人，医療機関や治療に関する選択の意 思決定をする人，治療代を支払う人といった 三者が同一の場合もあれば異なる場合もある。 患者本人だけでなく，その家族を含めた満足 の向上，不安の除去や軽減に努めるのが望ま しい 19)。

\section{(7)電子カルテ}

日本における電子カルテは 1995 (平成 7) 
年に亀田メディカルセンターで開始され, 現 在では電子ケアマップによって高度なクリテ イカルパスを作成することが可能となった ${ }^{20)}$ 。 もともとクリティカルパスは治療行為を標準 化させたものであるが，この電子ケアマップ ではオーダーメイドすることができるため, 標準化と同時に個別化が可能となった。

電子カルテのメリットには, データベース 化により，レントゲン写真や伝票の管理が容 易になること，ファイル共用に伴う情報の飛 躍的な蓄積, 連携医療機関との情報共有, 患 者の閲覧が可能になることなどが挙げられる。

木村・川越（2005）によると, 電子カルテ には次の 2 種類のシステムがある。1つは病 院とソフトウェアハウスや大手ベンダーが共 同開発したタイプであり，もう1つはグルー プウェアなどのアプリケーションを病院の SE が改良したタイプである。いずれにしても， 地域の中核病院がそれぞれ, 独自に電子カル テを開発し，近隣の医療連携先に教育するの が現状であるため，多額の資金を要する。

そのため，2005年度における電子カルテ稼 動病院数は 700 病院を数えるが, 普及率は $7.76 \%$ でしない（『月刊新医療』2006 年 11 月号)。政府は地域中核病院となる大病院にお いて $60 \%$ の普及率を目指していたが，現状 は $14.7 \%$ と大きな開きが生じている。普及が 進まない要因は資金の問題以外にも，電子力 ルテの導入企業が幾つかに分散されており (図一6)，規格が統一されていないことにあ る。規格の統一は医療機関だけでなく患者に とっても利便性が高まるので, 規格の統一を 早急に検討する必要がある。
口图-6

電子カルテ導入企業と導入数

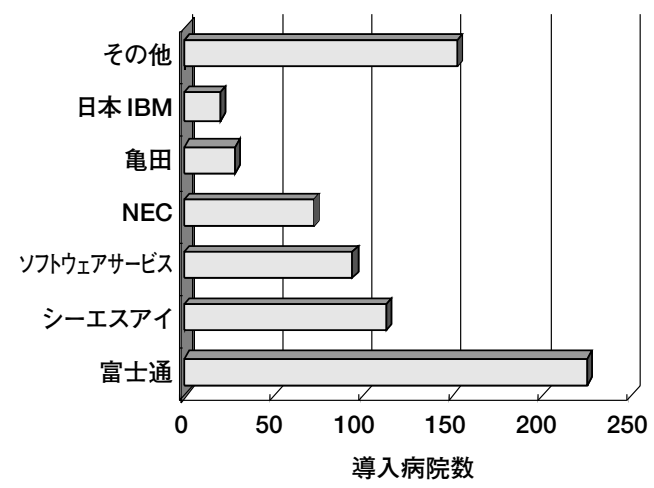

(『月刊新医療』2006 年 11 月号より作成)

\section{8 まとめ}

本稿では，一般的な医療機関が抱える内部 環境の課題として従業員満足と組織体型とを, 外部環境の課題として地域医療連携と患者満 足とを，また両方に共通する課題として電子 カルテを取り上げ，それぞれの具体的課題に ついて議論を展開した。医療連携は戦略的提 携の枠組みで議論することが可能であるが, 企業の場合, 戦略の 1 つの形として提携があ り，それを行うか否かは企業の戦略次第であ る。しかし，医療機関の場合，地域医療連携 は政府によって進められており，近年の機能 分化により個々の役割が明確化された医療機 関において医療連携の推進は避けることがで きない。これまでの議論は政策としての医療 連携であり，提供者視点によるものであるが, 患者にとっての利便性を考慮した医療連携を 同時に展開していく必要がある。同様に，電 子カルテも医療界特有の問題であるため, た くさんの課題が存在するが, 医療機関, 患者 
の両面から議論を積み重ねていかなければな らない。

また，医療機関を議論する際には，地方と 都会とを分けた議論や，急性期・亜急性期・ 回復期・慢性期・終末期に分けた議論が欠か せない。さらに，先述したように，患者を分 割した議論も必要であろう。いずれにしても， 医療に関しては高度な専門的知識が必要であ り，医療の質そのものに関する経営・マーケ ティング視点からの議論の展開は難しいが, 高い質の医療を継続的に生み出す医療組織の マネジメントに関する問題に目を向けたい。 経営学やマーケティング分野で医療を対象に した研究数は増加しているが，医療機関が抱 える課題は多岐に及んでおり，かつ我々国民 の生活に直結するものであるため，企業を対 象とした研究と同等以上の研究蓄積が望まれ る。そのため, 今後の研究課題を 3 つ提示す ることにより，本稿をむすびたい。

まず，本稿では株式会社による病院経営に ついては触れなかった。JR, NTT, 東京電力, トヨタ, 日立製作所などの企業が福利厚生施 設の一環として病院を設立しており，こうし た株式会社病院の中には医療技術, 医療経営, 地域住民との関係性の面で卓越した病院もい くつか存在する。これらの病院では, 親会社 である企業のビジネス知識がどのように病院 経営に活かされているのか, その知の移転を 明らかにすることは興味深い。あるいは，医 療機関のマネジメントから一般企業のマネジ メントへの応用も検討できるかもしれない。

また，電子カルテについては，先に述べた ように規格が統一化されていないことが大き な問題となっている。他の産業における標準 化のメカニズムと比較することにより，なぜ
電子カルテが統一化できないのかといった要 因を抽出していきたい。

もう $1 つ ，$ 近年の高齢化社会において，医 療機関は福祉サービスや在宅医療サービスと の連携を強めていかなければならない。地域 内で他の機関との共存の中で，地域住民の健 康増進への役割について再考する必要があろ う。

付記

本研究は「医療機関の満足度向上政策に関 する総合的研究」(学術振興会科学研究費補助 金（若手（B））（2005 年度～ 2007 年度)），静 岡大学人文学部若手研究者奨励研究（2007 年 度）の一部である。

\section{注}

1）『組織科学』では第 38 第 4 号で特集「医療・福祉 とマネジメント」が，また『ビジネス・インサイ 卜』では第 12 巻第 4 号で特集「医療経営を経営学 の視座で考える」が組まれている。

2）入院施設の有無により, 診療所は有床診療所と無 床診療所とに細分される。2007（平成 19）年 9 月 時点で有床診療所数は 12,407 施設, 無床診療所は 87,139 施設であるため，圧倒的に無床診療所の方 が多い(医療施設動態調查)。また，診療所には $\lceil\cdots$ 病院」という名称を用いることができず，多

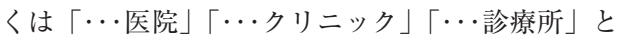
名付けられている。

3）その原因の 1つとして, 2004（平成 16）年から研 修医が研修先を自由に選べるようになったことが 指摘される（日本経済新聞 2007 (平成 19）年 12 月 11 日)。な押, それ以前は大学病院の医局が地方に 研修医を配置していた。さらには，症例数の多い 病院を医師が志向することや，生活利便性格差な ども医師が地方を避ける大きな要因である。

4）医療機関では「職員」を呼ぶことが一般的だが, 本稿では企業同様「従業員」と呼ぶ。

5）また，それぞれが専門的職種なため，企業で見ら れるような部署・部門間の人事異動はきわめて少 ない。

6) サービス・マーケティングにおいてまず組織内に 
目を向けることの重要性は Berry and Parasuraman（1992）によっても指摘されている。

7）製造における品質管理だけでなく，サービスやマ ネジメントなどにも全社的に $\mathrm{QC}$ 活動を広げたもの を TQC (Total Quality Control) と呼び, これが 発展したものがTQM（Total Quality Management）である。

8）静岡がんセンターでは副院長の 1 人には看護師が 就いている。多くの病院では医師がマネジメント の中心となっているが, 静岡がんセンターでは幹 部として経営に参画する看護師や, 経営管理を専 門に行うマネジメントセンターが存在する点が特 徵的である。

9）大病院とは 200 床以上を有する病院であり，20 床 以上 200 床未満の病院を中小病院という。

10) 2006 (平成 18）年 6 月の第 5 次医療法改正ではこ うした 1 次医療から 3 次医療に至るピラミッド型の 連携を解体し，疾病や事業の分類による水平的な 医療連携が推進されることとなった。2006（平成 18）年の診療報酬改定において「地域連携クリテ イカルパス」が導入され，2008 (平成) 年 4 月か ら始まる地域医療計画では 4 つの疾病（がん, 脳 卒中, 急性心筋梗塞, 糖尿病) と 5 つの事業（小 児救急医療, 周産期医療, 救急医療, 災害医療, 僻地医療）ごとに医療機関は診療ネットワークを 組み，地域連携クリティカルパスでつながれるこ ととなる。

11)都市部において機能分化は推進されやすいが，地 方においてはある程度のレベルの医療を総合的に 提供できる医療機関の存在が不可欠となる。しか し, 現行の診療報酬体系において後者の病院は低 く評価されてしまう。

12) Webster（1992）は戦略的提携と，日本に見られる ケイレツなど垂直的な相互依存関係における協力 関係とを区別した。一方，Gerlach（1992）は戦略 的提携とケイレツとの明確な区分が困難な場合も あると指摘した。医療連携にはさまざまな形態が あるがその多くは緩やかな組織間関係であり，ケ イレツの関係はきわめて少ない。

13) 反対に, 組織間ネットワークからパートナーの知 識を得ることができ, その結果, 信頼関係が促進 されるともいえる（Gulati and Gaugiulo 1999）。知 識の移転と信頼構築とがスパイラル上に拡大して いく関係が望ましい。

14)同様に, Mohr and Spekman（1994）は機会主義 的行動への不安が緩和されること，相手の自分に 対するコミットメントが高められる効果を指摘し ている。
15)恩田ら（2004）は，病院において薬の説明が患者 満足に与える影響を調査した。その結果，説明者 の傾聴態度の改善と, 薬剂管理指導業務の拡充が 重要であることを見出した。

16) 本稿では扱わないが, 情報提供の一形態として医 療広告が重要な役割を果たす。医療情報に関する 国民のニーズの高まりを受け，医療広告は規制緩 和の方向にある。「医業, 歯科医業若しくは助産師 の業務又は病院, 診療所若しくは助産所に関して 広告することができる事項」(平成 19 年厚生労働 省告示第 108 号）では, 医療従事者の氏名・年 齢・性別・役職および略歴, 医療従事者の専門性 に関して厚生労働大臣の認定を受けた旨，診療報 酬点数の算定方法に規定される検査や手術などの 治療方法, 手術件数, 平均入院日数, 患者数, 七 カンド・オピニオンの実績, 患者満足度に関する 調査実績の旨などの項目を記すことが緩和された。 これまで何度か規制緩和されているが，それでも 現時点における広告内容は国民のニーズとかけ離 れているのが実態である。その一方, 厚生労働省 はインターネットのホームページが広告に該当し ないと判断しているため, ホームページを用いて 積極的に情報提供に努める医療機関も多い（日本 医師会は，医療機関がホームページの内容を自主 的に判断するべきであると主張した上で，医療機 関のホームページのあり方に関するガイドライン を示している)。さらに, 多くの病院では情報提供 の一環として広報誌を作成している。

17）セカンド・オピニオンとは，診断や治療方針に関 する主治医以外の医師の意見を指す。セカンド・ オピニオン制度とは, 患者やその家族が自由にセ カンド・オピニオンを聞くことのできる環境を指 す。アメリカでは一般的となっているが, 日本で はまださほど普及していない。

18）入院の有無や，急性期，亜急性期，回復期，慢性 期，終末期といった受ける医療のタイプによる分 類も考えられる。

19）青梅慶友病院では老人病院という性格上, 特に家 族の満足度向上に努めている（大塚 2007）。

20)ケアマップとは，ある疾病に関する患者の病状や 状態の変化を具体的に表したものであり, クリテ イカルパスとは, 疾患ごとに治療内容を標準化し, 患者の入院から退院までのプロセスにおいて具体 的な治療や検査をスケジュール表のようにまとめ たものである。これにより，患者は自分の治療経 過や次段階の治療内容を知ることができる。 


\section{参考文献}

Berry, L.L. and A. Parasuraman (1992) , "Services Marketing Starts from within," Marketing Management, Winter, pp.25-34.

Das, T.K. and B.S. Teng (1998) , “Between Trust and Control : Developing Confidence in Partner Cooperation in Alliances," Academy of Management Review, Vol.23(3), pp.491-512.

Deci, E.L. (1972) , “The Effect of Contingent and NonContingent Rewards and Controls on Intrinsic Motivation," Organizational Behavior and Human Performance, Vol.8, pp.217-229.

Deci, E.L. (1975) Intrinsic Motivaiton, New York: Plenum Press（安藤延男·石田梅男訳『内発的動 機づけ』誠信書房，1980年）.

Dedhiya, S. and S.X. Kong (1995) , "Quality of Life : An Overview of the Concept and Measure," Pharmacy World \& Science, Vol.17(5), pp.141-148.

Donabedian A. (1980) The Definition of Quality and Approaches to its Assessment, Ann Arbor, MI: Health Administration Press.

Dyer, J.H. and W. Chu (2000) , “The Determinants of Trust in Supplier-automaker Relationships in the U.S., Japan and Korea," Journal of International Business Studies, Vol.31(2), pp.259-285.

Gerlach, M. (1992) Alliance Capitalism : The Social Organization of Japanese Business, Berkley, CA: University of California Press.

Gillon, R. (1986) Philosophical Medical Ethics, New York: John Wiley \& Sons.

Granovetter, M. (1973) , “The Strength of Weak Ties," American Journal of Sociology, Vol.78, pp.1360-1380.

Gulati, R. and M. Gaugiulo (1999) , "Where Do Interorganizational Networks Come from,” American Journal of Sociology, Vol.104(5), pp.293-317.

Hamel, G. (1991) , “Competition for Competence and Inter-partner Learning within International Strategic Alliances," Strategic Management Journal, Vol.12(special issue), pp.83-103.

Heller, D.A. (2006)「ラーニング・アライアンスのテ イーチング効果」アジア自動車産業研究会, 2006 年 2 月 2 日報告資料.

Inkpen, A.C. (1996) , “Creating Knowledge through Collaboration," California Management Review, Vol.39(1), pp.123-140.

Inkpen, A.C. (2000) , "Learning through Joint Ventures : A Framework of Knowledge Acquisition," Journal of Management Studies, Vol.37(7), pp.1019-1043.
Lindzey, G. and E. Aronson (1985) ,The Handbook of Social Psychology : Theory and Method, New York : Random House Inc.

McGregor, D. (1960) The Human Side of Enterprise, New York: McGraw-Hill（高橋達男訳『新版 企業の人間 的側面』産業能率短期大学出版部, 1970 年).

Maslow, A.H. (1954) Motivation and Personality, 2nd edition., New York: Harper \& Row（小口忠彦訳『人間 性の心理学-モチベーションとパーソナリティ 改 定新版』産業能率大学出版部, 1987 年) .

Ring, P.S. and A.H. Van de Ven(1992), “Structuring Cooperative Relationships Between Organizations,” Strategic Management Journal, Vol.13(7), pp.483-498.

Ring, P.S. and A.H. Van de Ven (1994) , “Developmental Process of Cooperative Interorganizational Relationships," Academy of Management Review, Vol.19(1), pp.90-118.

Uzzi, B (1997) , "Social Structure and Competition in Interfirm Networks : The Paradox of Embeddedness," Administrative Science Quarterly, Vol.42(1), pp.35-67.

Vroom, V. H. (1964) Work and Motivation, New York: John Wiley \& Sons（坂下昭宣・榊原清則・小松陽 一・城戸康彰訳『仕事とモチベーション』千倉書 房，1982 年）。

Webster,F.E.Jr. (1992) , “The Changing Role of Marketing in the Corporation," Journal of Marketing, Vol.56(4), pp.1-17.

Zimbardo, P.G. (1980) ,Essentials of Psychology and Life : Illinois : Scott Foresman \& Co. (邦訳『現代心理学 III』古畑和孝・平井 久監訳, サイエンス社, 1981 年）。

印南一路 (1998)「組織としての病院」『組織科学』組 織学会, Vol.31(3), pp.16-26.

大塚宣夫（2007）「豊かな最晚年をつくる〜サービス 業としての老人病院〜」鴆口研究会. 2007 年 11 月 19 日講演資料.

恩田光子・小林暁峯・黑田和夫 - 全田 浩 (2004) 「病院における薬の説明に対する患者満足度に影 響を与える要因に関する研究」『病院管理』病院 管理学会 Vol.41(1), pp.7-14.

木村憲洋・川越 満（2005）『病院のしくみ』日本実 業出版社.

酒向真理（1998）「日本のサプライヤー関係における 信頼の役割」藤本隆宏・西口敏宏 · 伊藤秀史編 『サプライヤーシステム』pp.91-118, 有斐閣.

高橋伸夫（1996）「組織均衡」『未来傾斜原理』白桃書 房, pp.85-105.

冨田健司（2003）「医療機関のリレーションシップ・ 
マーケティング」『病院管理』病院管理学会, Vol.40(2), pp.31-37.

水野 智 - 楊 舒 - 徐 知行 - 太田圭洋 - 山内一信

（1999）「患者満足度は医療の質の評価指標になり

うるのか」『病院管理』病院管理学会, Vol.36(4), pp.11-19.

山岸俊男（1998）『信頼の構造』東京大学出版会.

若林直樹（2006）『日本企業のネットワークと信頼』 有斐閣.

『月刊新医療』2006（平成 18）年 11月号，株式会社工 ムイー振興協会.

「医業, 歯科医業若しくは助産師の業務又は病院, 診 療所若しくは助産所に関して広告することができ る事項」(平成 19 年厚生労働省告示第 108 号)

「静岡県がんセンター（仮称）基本計画」静岡県, 1997 年

「静岡県がんセンター基本構想」静岡県，1996 年

「練馬総合病院 50 周年記念誌」

「練馬総合病院・病院案内」

日本経済新聞 2007 (平成 19) 年 12 月 11 日

オリコン患者満足度ランキング

http://isha.oricon.co.jp/interview/interview.html

亀田メディカルセンター

http://www.kameda.com/index.html

厚生労働省医療施設動態調査

http://www.mhlw.go.jp/toukei/saikin/hw/iryosd/ m07/is0703.html

厚生労働省統計表

http://www.mhlw.go.jp/toukei/saikin/hw/k-iryohi/ 03/toukei1.html

五の橋キッズクリニック

http://www.gonohashi-kids.or.jp/index.html

冨田 健司（とみたけんじ）

現職名：静岡大学人文学部経済学科准教授。

1994 年一橋大学商学部卒業, 1996 年まで株式会社 東海銀行に勤務した後，1998年一橋大学大学院商学 研究科修士課程修了。早稲田大学大学院商学研究科 博士後期課程単位取得, 早稲田大学大学院アジア太 平洋研究科助手を経て, 2002 年より現職。この間, 1998 年より 2002 年まで財団法人医療科学研究所に 研究員として勤務。2006 年 3 月から 2007 年 9 月ま でコロンビア大学, ボストン大学客員研究員。 